\title{
Republican win sparks fears for science funds
}

\section{Geoff Brumfiel, Washington}

With the Republicans wresting control of the US Senate from the Democrats in last week's mid-term elections, science leaders are starting to worry about the outlook for science funding in the United States.

Fears are growing that the Republican's dominance of both houses in the Congress will spell trouble for the future budgets of key science agencies. Prominent scientists are also worried that there will now be delays in the payment of grants and funds for building new facilities.

The priority for the Republican leadership over the next two months is the creation of the Department of Homeland Security. This means that long-standing disagreements over the 2003 budget are likely to wait until the new year.

"This will create some real problems for science," says Mike Lubell, director of public affairs at the American Physical Society. This December, the National Institutes of Health (NIH) was set to begin handing out grants from a massive \$3.7-billion boost it had expected to receive as the final instalment of a five-year budget-doubling process. And the National Science Foundation (NSF) was hoping to start building several projects and facilities that may now be delayed.

A bill that would have recommended doubling the NSF's budget over the next five years may also be in peril because the White House is reportedly not in favour of it (see Nature 419, 657; 2002).

The Republican takeover of the Senate will also stoke the debate over therapeutic cloning, says Kevin Wilson, director of public policy at the American Society for Cell Biology. In July of 2001, the House of Representatives passed a bill banning reproductive and research cloning. Since then the Senate has been debating whether cloning for research purposes should be allowed. That debate may shift under the leadership of Trent Lott (Republican, Mississippi), who is expected to take over as Senate Majority Leader, and who has opposed cloning in the past.

But a total ban is thought to be unlikely. "There are still some conservative Republicans who support research cloning," says Joanne Padrón-Carney, director of the Center for Science, Technology and Congress at the American Association for the Advancement of Science. Two such advocates, Arlen Specter (Republican, Pennsylvania) and Orrin Hatch (Republican, Utah), will chair committees that could prove influential in the debate.

Wilson still believes that the research community must redouble its efforts to convince Congress and the Bush administration of the virtues of research cloning. "Last year there was a threat of a comprehensive cloning ban," he says. "That threat

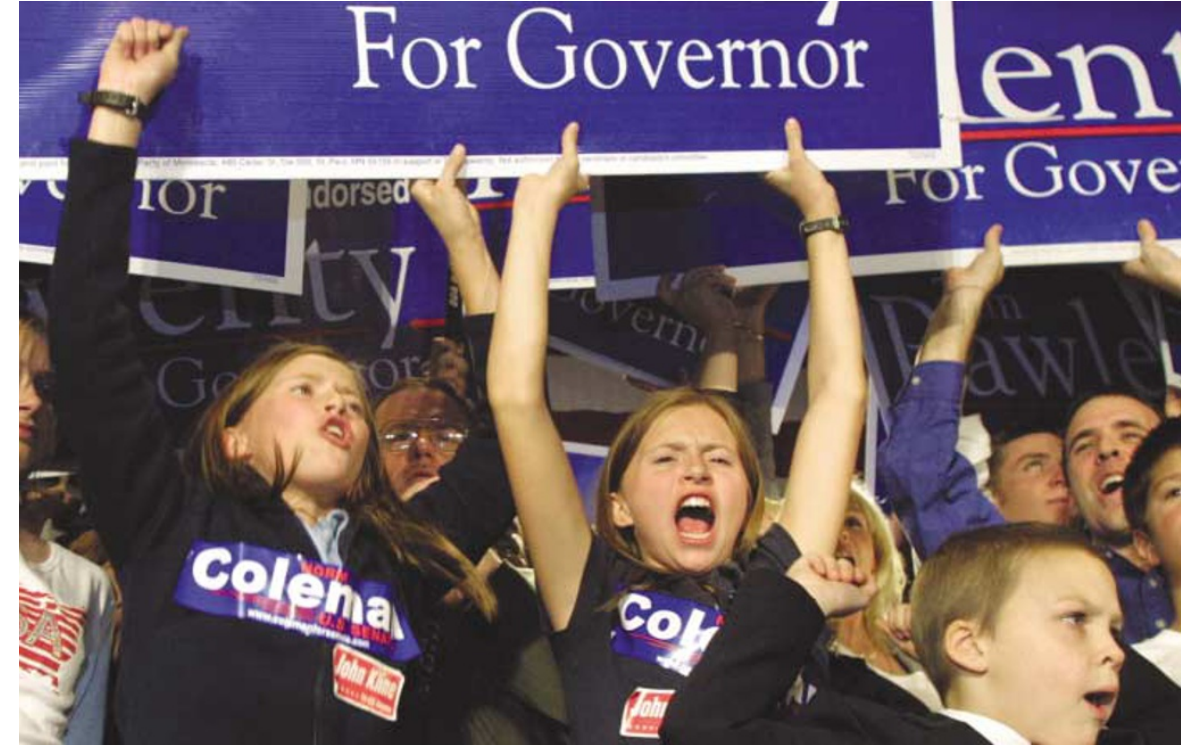

Victory: Republicans celebrate winning control of Congress in the mid-term elections.

has become a little more real to us."

The shift of power may signal difficult years ahead for research funding, scientists fear, as the recession and a possible Iraq con- flict push research further down the priority list. "In the coming year," says Lubell, "I think the discretionary budget for science is going to be exceedingly tight."

\section{Venus Express cleared for take-off}

Alison Abbott and Quirin Schiermeier

Europe's mission to Venus is no longer in any doubt. On 5 November, the European Space Agency (ESA) confirmed that Venus Express, scheduled for launch in 2005, will go ahead.

The mission to Earth's hotter neighbour was cancelled in May because of funding delays (see Nature 417, 474; 2002), but the decision caused such alarm in the space-science community that the agency rethought its plans. In July, ESA began work on the design phase of the mission, in anticipation of this month's final approval.

The fate of Venus Express had been in doubt because Italy could not finance one of the mission's most important instruments, the Visible and Infrared Thermal Imaging Spectrometer (VIRTIS), being developed at the Institute for Space Astrophysics in Rome. This instrument will detect the low levels of near-infrared radiation that escape Venus's thick atmosphere, and so allow scientists to study the composition of the planet's lower atmosphere.

ESA has now agreed to cover the costs of integrating the instrument into the spacecraft, even though it normally expects national space agencies to pay for scientific instruments. In return, ESA will publish a call for researchers from other member states to join the VIRTIS team.

"VIRTIS is a crucial instrument for the mission, and that's why we fought so hard for it," says a relieved Dmitri Titov, the mission's principal investigator, who is based at the Max Planck Institute for Aeronomy in Lindau, Germany.

But other projects were not so fortunate. DIVA, a planned German astrometry satellite to measure the position and movements of 35 million stars in the Milky Way, and planned for a 2004 launch, now looks unlikely to take off.

Germany had asked ESA to help close a 15-million-euro (US\$15.2-million) funding gap. But the agency's scientific advisers said that participation in DIVA could distract European astrometrists from ESA's cornerstone astrometry mission, GAIA, scheduled for launch in 2012.

Siegfried Röser, DIVA's principal investigator and a senior scientist at the Astronomisches Rechen Institute in Heidelberg, argues that DIVA would have been "an ideal precursor for GAIA in testing technology". But unless NASA accepts a proposal currently being considered by the US Naval Observatory in Washington DC for a US-German partnership on the mission, the ESA decision is the death knell for DIVA. 